\begin{tabular}{|c|c|}
\hline 54 & Malaysian Journal of Social Sciences and Humanities (MJSSH) \\
\hline Malaysian Journal of & Volume 5, Issue 12, December 2020 \\
\hline (MJ-sSH) & e-ISSN : 2504-8562 \\
\hline & $\begin{array}{l}\text { Journal home page: } \\
\text { www.msocialsciences.com }\end{array}$ \\
\hline
\end{tabular}

\title{
Mahathiriskonomism dan Elemen Diplomasi Ekonomi dalam Pengurusan Ekonomi Malaysia Berhadapan Krisis Ekonomi 1997/98
}

\author{
Md. Shukri Shuib ${ }^{1}$, Mohamad Faisol Keling1, Nazariah Osman'1 \\ ${ }^{1}$ School of International Studies (SOIS), College of Law, Government and International Studies, \\ Universiti Utara Malaysia (UUM) \\ Correspondence: Md. Shukri Shuib (wacanashukri@gmail.com)
}

\begin{abstract}
Abstrak
Krisis ekonomi 1997/98 melanda Malaysia secara mendadak, namun proses pemulihan telah dilaksanakan oleh kerajaan Malaysia dilakukan tepat pada masanya kerana wujud dasar atau polisi yang dihasilkan oleh kepintaran pengurusan Malaysia itu sendiri. Melalui tindakan Mahathirisasi dan komponen pengurusan yang jelas, disokong oleh kekuatan kepemimpinan Dr. Mahathir Mohamad, tulang belakang pasukan pengurusan dan gaya kepemimpinan yang berkesan telah membawa formula Malaysia dalam menangani krisis ekonomi 1997/998 yang dikenali melalui pendekatan Mahathiriskonomism. Pendekatan yang melibatkan unsur diplomasi ekonomi sebagai kaedah yang digunakan oleh Malaysia untuk menghadapi dan bertahan dari tekanan ekstrem yang melanda Malaysia pada bulan Ogos 1998, menyebabkan penurunan tertinggi dalam nilai tukar mata wang Ringgit Malaysia (RM), tekanan terhadap rizab asing dan juga kenaikan kadar faedah. Krisis ekonomi 1997/98 menimbulkan kesan besar kepada Malaysia dengan mempengaruhi visi dan perancangan pembangunan ekonomi, menyebabkan gangguan pada garis masa dan perancangan yang cuba dicapai oleh kerajaan. Sektor perbankan dan korporat paling banyak terkena dampak krisis ekonomi ini, dan ini sangat membimbangkan pemerintah. Dalam proses menangani kemerosotan ekonomi dan mengatur langkah pemulihan ekonomi, kerajaan semasa kepimpinan Dr. Mahathir Mohamad berjaya bertindak balas dengan memperkenalkan sistem bertentangan yang diamalkan oleh Thailand dan Indonesia, di mana mereka menerima bantuan IMF. Majlis Tindakan Ekonomi Nasional (NEAC) dibentuk pada 7 Januari 1998 untuk menguruskan krisis ekonomi dan mengurangkan jurang antara sektor kerajaan dan swasta. NEAC di bawah kepemimpinan Tun Dr. Mahathir Mohamad membina kerangka tindakan yang dinamakan Pelan Pemulihan Ekonomi Negara (PPEN), yang telah memberi kesan positif, terbukti berjaya memberikan kestabilan dan keyakinan di pasaran, memperkuat kedudukan ekonomi rakyat. Melalui mekanisme pengurusan yang terbentuk dengan baik, elemen Diplomasi Ekonomi menyuburkan usaha pemulihan ekonomi. Hubungan baik Malaysia menerusi kepimpinan Dr. Mahathir Mohamad dengan Jepun dan China berdasarkan aplikasi Dasar Pandang ke Timur berperanan positif sebagai asas pemulihan ekonomi Malaysia. Objektif utama penulisan ini adalah untuk mengenal pasti pendekatan pengurusan bersama aplikasi 'diplomasi ekonomi' bersama pendekatan Mahathirriskonomism yang dipelopori oleh Tun Dr. Mahathir Mohamad telah membantu Malaysia keluar dari kegawatan krisis ekonomi 1997/98. Aplikasi Diplomasi ekonomi Tun Dr. Mahathir Mohamad yang dilaksanakan dalam pendekatan Mahathiriskonomism menggambarkan bahawa amalan diplomasi ekonomi yang positif adalah tonggak utama penyelesaian yang berjaya digembleng semasa berhadapan krisis ekonomi.
\end{abstract}

Kata kunci: diplomasi ekonomi, Mahathiriskonomism, pemulihan ekonomi 


\title{
Mahathiriskonomism and the Elements of Economic Diplomacy in Malaysian Economic Management During Economic Crisis 1997/98
}

\begin{abstract}
This paper focuses on the practice and approach as well as the role of Tun Dr. Mahathir in resolving the 1997/98 economic crisis and focuses on the construction of a concept called Mahathiriskonomism. Clearly, Tun Dr. Mahathir played the role and construction of "ism" based on his thought patterns and leadership model to help Malaysia get out of the crisis of the economic crisis without the need for foreign aid that plagued the country's political and economic system. The 1997/98 economic crisis occurred suddenly for Malaysia and through the recovery process implemented by the government, it was successfully done quickly due to the existence of policies generated by Malaysia's own management. Mahathirization and clear management elements, underpinned by Tun Dr Mahathir's leadership strength and personality, together with his professional management team have unveiled Malaysia's formula in dealing with the 1997/98 economic crisis. The approach to addressing and recovering from the 1997/98 economic crisis triggered a formula and concept called Mahathiriskonomism. The depreciation of the ringgit and the occurrence of the financial crisis that impacted the economic sector are seen as an event that changed the approach of political and economic management in Malaysia. The current economic crisis has an impact on Malaysia by affecting the vision and planning of economic development and causing disruption to planning to achieve the progress targeted by the government. The 1997/98 economic crisis had a major impact on various sectors, especially banking, finance and corporate, and it also worried the government. The process of dealing with the crisis and implementing economic recovery, the Malaysian government led by Tun Dr. Mahathir Mohamad through the Barisan Nasional mandate managed to respond to the crisis and introduced its own way compared to the policies and actions practiced by Thailand and Indonesia that receive international assistance, especially the IMF. Professional management through the establishment of the National Economic Action Council (NEAC) on 7 January 1998 aims to manage the economic crisis and reduce the gap between the government and the private sector, and this is a measure of the Mahathirization of the country's administration during the crisis. MTEN measures introduced by the leadership of Tun Dr. Mahathir Mohamad with the production of a framework called the National Economic Recovery Plan (PPEN) created based on orientation towards the stabilization of the value of the Malaysian Ringgit in the international currency market has given a positive effect that it has proven successful in restoring investor confidence in the market and economic position Malaysia. MTEN through PPEN which is also oriented to maintain financial stability, strengthen economic and equity foundations are found to be successfully implemented effectively, and it succeeds in the application of Mahathiriskonomism in the management of the country during the political and economic crisis.
\end{abstract}

Keywords: economy diplomacy, Mahathiriskonomism, economic recovery

\section{Pengenalan}

Wujud pelbagai kajian mengenai cara Malaysia menghadapi dan menangani krisis ekonomi 1997/98, tetapi ia hanya berkisar soal mekanisme dan cara semata-mata tanpa melibatkan fokus yang khusus mengenai peranan Tun Dr. Mahathir Mohamad sebagai Perdana Menteri yang mengetuai usaha menangani permasalahan yang berlaku. Mengkaji fenomena dan hasil tanpa mempedulikan aktor yang bertanggungjawab dalam memimpin negara berhadapan krisis ekonomi 1997/98 itu adalah satu usaha yang belum lengkap secara akademiknya. Kertas kerja ini melihat dimensi peranan Tun Dr. Mahathir dalam menguruskan negara dari sudut ekonomi dan politik serta mengkaji impak yang diterima hasil dari cara pengurusan beliau semasa krisis tersebut. Menurut Institute for International Economics, di kalangan empat buah negara Asia yang dilanda krisis ekonomi 1997/98 kajian mendapati bahawa hanya Malaysia sahaja yang mencatatkan sejarah politik ekonomi di mana kerajaan semasa tidak berubah akibat dari kesan peristiwa krisis ekonomi 1997/98 yang berlaku. Indonesia, Thailand serta 
Korea Selatan yang juga dikaji dalam kajian institut berkenaan mengalami perubahan rejim pemerintah. Persoalan timbul adalah berkaitan dengan kaedah yang diguna pakai oleh Dr. Mahathir dalam menyelesaikan permasalahan ekonomi dan pergolakan politik secara serentak. Kertas kerja ini secara khususnya memfokuskan kepada satu hipotesis bahawa peranan yang dilaksanakan oleh Dr. Mahathir Mohamad menggunakan diplomasi ekonomi sebagai kaedah memimpin Malaysia menghadapi krisis ekonomi yang melanda Asia serta Malaysia pada 1997-1998 adalah begitu signifikan. Kedudukan Dr. Mahathir selaku Perdana Menteri pada ketika itu telah membolehkan beliau bertindak sebagai pemikir dan pencetus kepada solusi atau mekanisme penyelesaian krisis, dan juga mampu menggunakan kedudukan eksekutifnya dalam membentuk pasukan khusus bagi bekerjasama sebagai pemikir (think-tank) serta bertindak balas dengan pembentukan polisi serta tindakan yang bersesuaian.

\section{Peristiwa Krisis Ekonomi 1997/98}

Krisis ekonomi yang melanda Asia termasuk Malaysia pada 1997/98 itu telah mengalihkan pandangan dunia yang turut sama melihat kepada aspek keterlibatan pasaran dan sistem kewangan antarabangsa melibatkan peranan dan keberkesanan dalam menangani krisis ekonomi. Krisis ekonomi yang melanda juga menunjukkan bahawa ia juga disebabkan oleh perubahan dalam arah aliran modal antarabangsa di pasaran modal tempatan sehingga menyebabkan keadaan yang tidak stabil kepada pasaran disebabkan oleh tindakan drastik untuk mengubah haluan pasaran sehingga mewujudkan peralihan dalam keyakinan pasaran (Radelet \& Sachs, 1998). Krisis ekonomi yang melanda Malaysia dan negara serantau di Asia Timur masih diingati sebagai satu peristiwa terpenting dunia dan negara, ini dapat dilihat dengan jelas menerusi ucapan mantan Perdana Menteri Malaysia keenam, Datuk Sri Mohd Najib Tun Haji Abdul Razak pada 29 November 2014 dengan menyatakan bahawa dalam tahun 1997 ekonomi Malaysia merudum yang mengakibatkan kewangan negara menjadi lemah dan prestasi pembangunan juga merosot (Mingguan Malaysia, 2014). Kegawatan ekonomi yang melanda Malaysia pada 1997 memberikan beberapa kesan kepada Malaysia dalam aspek ekonomi, sosial dan juga aspek politik.

Sebelum Julai 1997, kedudukan ekonomi negara-negara Asia Timur berkembang pesat dan maju. Kejatuhan nilai mata wang kemudiannya menjadikan kedudukan ekonomi dan kewangan negaranegara terlibat di Asia Timur semakin terjejas. Bath iaitu mata wang Thailand mula mengalami susutan nilai berbanding mata wang asing yang begitu ketara bermula Julai 1997 menjadikan petanda kemerosotan nilai mata wang satu persatu negara-negara Asia Timur. Krisis kewangan yang melanda Asia bermula 14 Mei 1997 apabila berlakunya serangan spekulasi ke atas mata wang Baht dan kegagalan kerajaan Thailand mempertahankan kedudukan nilai mata wang Baht sehingga menyebabkan berlakunya kegagalan beberapa buah syarikat kewangan di negara tersebut pada 23 Mei tahun yang sama (Aaron, 2000). Ketika krisis berlaku, Tun Dr. Mahathir telah menolak cadangan dan dana bantuan daripada Dana Kewangan Antarabangsa (IMF) yang beliau sifatkan akan memburukkan lagi krisis itu (pandangan Amin Iskandar di dalam Kebebasan bawa erti besar bagi negara, Berita Harian, 2013). Inilah yang dirangkumkan oleh Md. Shukri sebagai Mahathiriskonomism, iaitu pendekatan khusus secara ilmiah memperincikan impak hasil usaha kerajaan pimpinan Tun Dr. Mahathir bersama aplikasi Diplomasi Ekonomi dan pemimpin bersamanya dalam memulihkan negara dari kesan buruk krisis ekonomi 1997/98. Dalam konteks ini, Prema-chandra (2010), telah menegaskan bahawa walaupun Malaysia dilanda kegawatan, pembuat dasar Malaysia dapat menghadapi situasi getir tersebut dengan cara tersendiri berbanding Thailand dan Indonesia yang lebih pantas beralih kepada IMF sebagai alternatif. Ini menunjukkan bahawa kepimpinan dan juga pembuat dasar negara memainkan peranan penting, usaha Tun Dr. Mahathir yang paling diingati masyarakat Malaysia dan antarabangsa ialah ketika kejayaan beliau membawa Malaysia keluar dari Krisis Kewangan Asia pada 1997. 


\section{Pengertian Diplomasi Ekonomi}

Konsep diplomasi secara klasik adalah dikaitkan antara "perlakuan hubungan antara negeri dan entiti lain dengan kedudukan dalam politik dunia oleh ejen rasmi dan dengan cara perdamaian' (Bull, 1977). Diplomasi berkaitan dengan pengurusan hubungan antara negeri dan antara negeri dengan pelaku lain (Barston 2006). Tetapi definisi ini seolah-olah stereotaip, seolah-olah diplomasi hanya dilakukan oleh diplomat dan elit.

\section{Apa itu 'diplomasi ekonomi'?}

Diplomasi ekonomi bukan sekadar subjek kajian akademik, ia adalah aktiviti yang dilakukan oleh elemen negeri sebagai aktor dengan aktor bukan negara. Diplomasi ekonomi mementingkan masalah dalam sistem ekonomi antarabangsa. Sistem institusi ekonomi antarabangsa Bretton Woods yang diciptakan setelah Perang Dunia II didasarkan pada apa yang disebut oleh John Ruggie sebagai 'liberalisme' (Ruggie, 1982). Ini bermaksud bahawa sistem itu mengembangkan peraturan untuk hubungan ekonomi antara negara, tetapi membiarkan autonomi ekonomi nasional sebahagian besarnya tidak tersentuh. Selagi dasar-dasar dasar domestik tidak memberi kesan negatif kepada pihak lain, pemerintah dapat melaksanakan apa saja pekerjaan, cukai atau dasar industri yang mereka inginkan. Tetapi peningkatan saling ketergantungan ekonomi selama 60 tahun terakhir telah mengakhiri perbezaan yang rapi antara apa yang domestik dan apa itu kebijakan antarabangsa. Kemajuan globalisasi sejak tahun 1990 mewajibkan diplomasi ekonomi masuk ke dalam pembuatan keputusan dalam negeri. Ini menjadikan diplomasi ekonomi menjadi lebih kompleks, membawa lebih banyak isu dan lebih banyak pelaku.

\section{Aktor Negeri dan Bukan Negara}

Diplomasi ekonomi terutama berkaitan dengan apa yang dilakukan oleh pemerintah, dalam definisi yang paling luas. Ini jauh lebih luas daripada kementerian asing atau mana-mana kalangan birokrat tertutup. Semua agensi kerajaan yang mempunyai tanggungjawab ekonomi dan beroperasi di peringkat antarabangsa terlibat dalam diplomasi ekonomi, walaupun mereka mungkin tidak menggambarkannya seperti itu. Menteri-menteri dan ketua-ketua kerajaan, parlimen, agensi awam bebas dan badan-badan sub-nasional semuanya merasakan pengaruhnya. Sebilangan besar pelaku bukan negara juga terlibat dalam diplomasi ekonomi, baik dengan membentuk dasar pemerintah dan sebagai pemain bebas sendiri. Pada masa lalu, perniagaan cenderung menjadi kumpulan minat yang paling aktif. Kini badan bukan kerajaan (NGO), yang dikelompokkan sebagai masyarakat madani, telah menjadi pusat perhatian. Organisasi antarabangsa penting sebagai forum rundingan.

\section{Konsep Mahathiriskonomism}

Pengistilahan Mahathiriskonomism terbit dari kombinasi nama 'Mahathir', iaitu mantan Perdana Menteri Malaysia keempat, dan digabungkan dengan kata 'risiko ekonomi' bersama 'ism' yang membawa erti pemikiran atau ideologi (Md. Shukri, 2007). Mahathiriskonomism sebagai satu konsep ilmiah telah diketengahkan yang secara umumnya didefinisikan sebagai paradigma atau pemikiran Mahathir berkaitan dalam pengurusan risiko ekonomi yang dihadapi Malaysia semasa pentadbiran beliau sebagai Perdana Menteri Malaysia, terutama ketika melakukan tindakan pemulihan krisis ekonomi 1997/98 (Md.Shukri, Mohamad Faisol \& Mohd Na'eim, 2008). Mahathiriskonomism adalah satu pendekatan mengurus dan menangani risiko ekonomi secara khususnya, dan merupakan pendekatan lebih luas menjangkau pemikiran dan kerangka ideologi konsep politik, ekonomi dan sosial yang sering dinyatakan oleh Md. Shukri (2007) sebagai elemen penting disebut 'trifungsi sejagat'. Pentingnya Mahathiriskonomism ialah ia bercirikan keberanian mengambil risiko dengan konsep pantang berundur.

Mahathiriskonomism dalam tindakan menangani krisis ekonomi 1997/98 semestinya mencirikan pendekatan Mahathirism sebagai teras, iaitu pendekatan berasaskan gaya kepimpinan dan pemikiran Dr. Mahathir yang tersendiri dan bebas dari pengaruh asing. Pandangan ini disesuaikan juga menerusi 
pengamatan Dr Rais Yatim (2011) yang mengemukakan rumusan berkenaan dengan usaha dan langkah yang dilaksanakan serta dasar termasuk aspek kepimpinan Tun Dr. Mahathir bahawa istilah Mahathirism itu adalah istilah yang boleh digunakan dalam menyatakan segala hal berkaitan Mahathir. "Despite his golden years of nearing 90, Mahathir and indeed Mahathirism - if there be such a term that can be used to describe all things Mahathir" (Rais Yatim, 2011: 237). Aspek Mahathirism ini secara jelas diperincikan bahawa ia tidak mempunyai batasan dalam waktu dan tindakan, bahkan apa sahaja tindakan Dr. Mahathir dalam pentadbiran dan tingkah laku beliau mampu dikategorikan sebagai Mahathirism (Rais Yatim, 2011).

\begin{abstract}
Mahathir became Mahathirism in many ways. He had his own way of doing things and not many had the dash of mind and psysical vigoutr to achieve what he achieved
\end{abstract}

(Rais Yatim, 2011:245)

Terdapat dua faktor utama di kategorikan Dhillon (2008; Johan, 2010) dalam perkiraan Dr. Mahathir menjana polisi negara, iaitu faktor dalaman (domestic) dan faktor luaran (external) dan ini menjadikan elemen idiosinkratik (idiosyncracies) atau kewibawaan ketokohan Dr. Mahathir itu sendiri memberi kesan besar terhadap pembinaan dasar serta polisi yang kukuh bagi Malaysia berhadapan dengan masyarakat Malaysia dan antarabangsa.

Johan (2010) menyatakan bahawa Dr. Mahathir telah membawa elemen dikenali sebagai 'ikonoklasme' sebagai elemen peneraju terhadap pembikinan dasar di Malaysia yang berkisar terhadap wawasan yang beliau sendiri janakan. Penggubalan dasar dan pengubah suaian sesuatu polisi adalah menjadi satu keutamaan di era Dr. Mahathir dengan mengambil kira beberapa aspek seperti perubahan era dengan mengambil kira aspek yang tidak dapat dielakkan seperti globalisasi. Sesuatu dasar di Malaysia yang dijanakan juga mengambil kira peranan kepimpinan Dr. Mahathir yang berwatak agresif dalam mencapai matlamat kepentingan nasional (Johan, 2010). Ini disebutkan Dhillon (2008) sebagai Mahathir's idiosyncracies. Dr. Mahathir dikenali sebagai Perdana Menteri dan pemimpin yang begitu rajin bekerja. Rais Yatim menyatakan hal ini dalam penulisan beliau dengan tulisannya "In Abdullah's psyche is the determination of how to continue a job that has been synonymous with a methodical workaholic, a methaphor which Mahathir has been well known for" (Rais Yatim, 2011: 239). Mahathiriskonomism dengan ciri terasnya iaitu Mahathirism dalam konteks tindakan dan tingkah laku dilaksanakan bagi mendepani krisis ekonomi 1997/98 dapat dilihat menerusi tindakan drastik yang dilaksanakan, antaranya dengan pertentangan politik dan perbezaan pendekatan ekonomi dalam antara Dr. Mahathir dengan Timbalan Perdana Menteri yang juga menteri kewangan ketika itu Datuk Seri Anwar Ibrahim, dan Dr Mahathir. dengan sifat Mahathirism tersendiri dengan gaya dan pendekatannya mengambil tindakan drastik bukan sahaja melakukan perubahan dasar, tetapi bertindak menyingkirkan timbalan beliau sendiri, dan kemudian-nya bertindak dengan gaya tersendiri bagi menyelesaikan krisis ekonomi yang dihadapi negara. Rais Yatim (2011) menyatakan bahawa:-
In 1997 in the midst of the world's worst financial crisis Mahathir, contrary to the stand of his deputy, Anwar Ibrahim, introduced a sea of change in Malaysia's economic and fiscal basics. He caused to be mopped the Malaysian ringgit overseas so as rendering it to be non legal tender. The ringgit poured back into the country. As incentive, he even chose not to tax anyone who brought back huge sums of money into the country. He then disallowed capital outflow. (Rais Yatim, 2011: 245).

Menurut Jomo (2007), pentadbiran Tun Dr. Mahathir sebagai Perdana Menteri Malaysia pada tahun 1997 hingga tahun 2003 disebutkan sebagai fasa "pengurusan krisis" (crisis management, 1997-2003). Krisis ekonomi 1997/98 memberikan kesan pengucapan ke atas agenda mentransformasikan politik ekonomi Malaysia, dan ianya juga memberikan kesan yang sama ke atas kebanyakan negara Asia Tenggara (Johan, 2010:300). Jomo (2007) membahagikan era pentadbiran Tun Dr. Mahathir kepada tiga fasa, iaitu:

i. $\quad$ Fasa pembangunan industri berat (heavy industrialization) (1981-1985)

ii. Fasa liberalisasi ekonomi (1986-1997) 


\section{iii. Fasa pengurusan krisis (crisis management) (1997-2003)}

Selain itu, Mahani (2002) menggariskan beberapa faktor penting dalam aspek kepimpinan yang membawa kejayaan Dr. Mahathir sebagai pengurus yang baik dalam menyelesaikan krisis ekonomi 1997/98. Antara faktor-faktor itu ialah:

i. Legitimasi

ii. Kemahiran berfikir secara strategic (strategic thinking skill)

iii. Visi dan misi (vision and mission)

iv. Rekod pencapaian yang terbukti (proven track record)

v. Pengorganisasian mekanisme pengurusan krisis (Organisation of Crisis Response Machinery)

Langkah Mahathiriskonomisme dalam penyelesaian krisis ekonomi 1997/98 dapat dilihat secara ketara menerusi langkah-langkah berikut:

i. Mahathir mengambil alih posisi sebagai Menteri Kewangan dan mengawal keseluruhan fungsi penting sistem ekonomi dan kewangan negara. Konsep perdana menteri sebagai menteri kewangan mula menjadi tradisi dalam sistem eksekutif di Malaysia sejak 1998 hingga kini.

ii. Pemusatan proses pembuatan keputusan secara kolektif dengan penubuhan sebuah majlis tindakan khusus iaitu Majlis Tindakan Ekonomi Negara (MTEN) bersama kewujudan Pelan Pemulihan Ekonomi Negara (PPEN). Ini adalah langkah penginstitusian yang menguasai langkah ekonomi yang diambil kerajaan.

iii. Kawalan modal dan penetapan kadar tukaran mata wang asing berbanding RM adalah satu senjata utama yang berjaya di formulasikan dengan berkesan. Langkah ini seolah menyimpan deposit asing untuk jangka masa tertentu dan mengelakkan pengunduran dana asing secara mendadak dari pasaran kewangan Malaysia. Ia membantu per unjuran wang dan dana sedia ada dalam pasaran oleh kerajaan.

iv. Penggabungan bank serta kewujudan institusi insurans pendeposit mewujudkan keyakinan pasaran awam kepada institusi kewangan semasa.

v. Kewujudan Dana Harta dan Dana Modal sebagai langkah pro aktif melindungi modal dan harta peniaga di Malaysia dari jatuh ke tangan asing telah memberi kesan nasionalisme ekonomi yang positif.

Menurut Md. Shukri (2008), menerusi model Mahathiriskonomism, wujud keberkesanan yang efektif dalam pengurusan stres ekonomi, dan ini dibuktikan dengan keupayaan aplikasi model Mahathiriskonomism di Malaysia. Menerusi aplikasi Mahathiriskonomism, ia telah melonjakkan pertumbuhan Malaysia dari -7.5 peratus pada 1997 dengan pertumbuhan sebanyak 13.3 peratus kepada 5.8 peratus pada 1999. Pertumbuhan itu mengulangi kejayaan pimpinan Tun Dr. Mahathir semasa menangani krisis ekonomi 1985 dengan kadar pertumbuhan mencecah -1 peratus kepada 1.2 peratus (1986) dan 8.7 peratus (1988).

\section{Pendekatan Diplomasi dan Mahathiriskonomism dalam Pengurusan Krisis Ekonomi}

Krisis ekonomi 1997/98 berlaku secara mengejut bagi Malaysia dan menerusi proses pemulihan dilaksanakan kerajaan, ia berjaya dilakukan dengan pantas kerana wujudnya polisi yang dijanakan oleh pengurusan Malaysia sendiri (Mahani, 2002). Dr. Mahathir berjaya memahami situasi yang berlaku dan cepat bertindak ke arah penyelesaian krisis. Malaysia di bawah pentadbiran diketuai Dr. Mahathir berjaya menyediakan negara dengan kaedah tersendiri penyelesaian krisis ekonomi tanpa perlu mengikut terma dan syarat yang ditawarkan IMF melalui kaedah pemulihan ekonomi yang disediakan (Mahani, 2002), ini menunjukkan dengan jelas dan tepat bahawa pendekatan Mahathiriskonomism adalah satu kaedah unik dalam membantu pemulihan negara dari krisis ekonomi yang melanda. 
Menurut Weller dan Hersh (2002), masalah utama negara-negara Asia adalah aliran modal yang drastik. Selama 20 tahun pasaran modal mengalir tanpa kawalan. Ini terbukti melalui peningkatan modal asing dari negara maju ke negara membangun. Kenaikan ini dapat dibandingkan dengan kenaikan tahun 1980 yang hanya mengalami aliran modal US \$ 1.9 bilion hingga US \$ 120.3 bilion pada tahun 1997. Ini jelas menunjukkan masalah kewangan di pasaran domestik negara-negara Asia termasuk ASEAN dan Malaysia, yang merupakan ketidakmampuan mengawal aliran keluar modal asing yang drastik seperti apa yang dilaksanakan oleh pelabur asing semasa krisis kewangan Asia 1998. Apabila negara-negara Asia mengalami kemuflisan, pengambilalihan syarikat asing dari pelabur asing telah menarik minat pelabur baru, ini dapat dilihat pada tahun 1998 sahaja, masih ada minat pelabur asing untuk melabur sehingga AS \$ 56 bilion di pasaran domestik negara-negara Asia.

Dr. Mahathir berjaya memahami situasi yang berlaku dan cepat bertindak ke arah penyelesaian krisis. Malaysia di bawah pentadbiran diketuai Dr. Mahathir berjaya menyediakan negara dengan kaedah tersendiri penyelesaian krisis ekonomi tanpa perlu mengikut terma dan syarat yang ditawarkan IMF melalui kaedah pemulihan ekonomi yang disediakan melalui Diplomasi Ekonomi dan Mahathriskonomism menjadi teras aplikasi. Dr. Mahathir sanggup mengadakan penerangan awam ke serata Malaysia sepanjang Julai 1998 bagi menerangkan situasi yang berlaku akibat krisis ekonomi yang melanda negara kepada pemimpin dan rakyat untuk difahami. Selain dari perhimpunan rakyat, Dr. Mahathir juga bertemu dengan kebanyakan pemimpin, menjelajah serata bandar sebelum langkah seterusnya dilakukan bagi menangani krisis ekonomi terutamanya apabila kawalan modal dan mata wang hendak dilaksanakan kerajaan (Mahani, 2002).

Dhillon (2009) turut menegaskan bahawa aspek polisi serta dasar yang dijalankan Malaysia pada era kepimpinan Dr. Mahathir juga banyak tertumpu kepada penumpuan usaha kepada aspek pembangunan. Pendekatan Mahathiriskonomism ini merupakan satu kerangka yang universal dan mampu diaplikasikan di dalam semua lapangan pendekatan pembangunan bukan sahaja di Malaysia, namun ia mampu memberikan model kepada negara-negara ekonomi sedang membangun termasuk juga kepada dunia maju sendiri.

Malaysia mengenal pasti IMF bukan sebagai alternatif bantuan dalam menyelesaikan krisis. Jepun sebagai rakan utama bagi Malaysia adalah alternatif bagi Malaysia untuk membantu dalam menghadapi krisis ekonomi. Dr. Mahathir percaya bahawa Asia Timur berpotensi mengukuhkan pasaran bersifat regional, dan menerusi gagasan ASEAN+3 (Jepun, China dan Korea Selatan), bersama kerjasama serantau meliputi Asia Tenggara dan Asia Timur, Jepun mempunyai keupayaan untuk mengambil peranan sebagai kuasa besar serantau dari segi ekonomi. Potensi Jepun ini jelas diperlihatkan oleh Dr. Mahathir sebagai satu platform amalan diplomasi ekonomi yang positif. Jepun yang merupakan negara sahabat kepada Malaysia, melihat kepada kejayaan yang dicapai oleh Malaysia dalam menguruskan ekonomi, maka Jepun bertindak memberikan kesediaan jaminan terhadap bond yang keluarkan Malaysia di pasaran antarabangsa. Perkara ini secara peribadi disebut oleh Dr. Mahathir yang mengesahkan bahawa ketika Malaysia memerlukan pemulihan krisis ekonomi, Jepun telah menawarkan bantuannya:

"Japan came to the rescue by making available substantial soft loans amounting to
several billion US dollars. Japan was also prepared to guarantee any bond issue
by the Malaysian Government. And so despite Moody's and Standard and Poor's
low ratings, when the Government tested the American bond market in 1999, the
issue was oversubscribed by three times."
(Mahathir, 1999).

Langkah yang mendapat sokongan Jepun itu jelas memaparkan bahawa aplikasi Diplomasi Ekonomi menerusi pendekatan Mahathiriskonomism dalam pengurusan krisis ekonomi adalah satu mekanisme yang membantu Malaysia mengatasi krisis yang berlaku.

Diplomasi ekonomi ini jelas dilihat oleh Prof. Stiglitz sebagai satu elemen yang berjaya diaplikasikan secara positif oleh kepimpinan Dr. Mahathir dalam mengatasi krisis ekonomi 1997/98 yang melanda Malaysia dan Asia. 


\begin{abstract}
"Malaysia was severely criticized during the crisis by the international financial community. Though Prime Minister Mahathir's..., many of his economic policies were a success" (2002: 122).
\end{abstract}

Langkah Diplomasi Ekonomi yang digunakan Tun Dr. Mahathir jelas dinyatakan menerusi Dhillon (2009: 93) bahawa kerajaan Jepun telah bertindak menjanjikan bantuan sebanyak US $\$ 80$ bilion kepada negara-negara Asia yang terlibat dalam krisis ekonomi yang melanda pada 1997/98. Kesan positif aplikasi Diplomasi Ekonomi memperlihatkan Malaysia menerima bantuan Jepun sebanyak US\$7.6 bilion dalam bentuk bantuan bilateral, dan ini menjadikan Malaysia sebagai penerima terbesar bantuan kewangan Jepun ketika krisis ekonomi 1997/98. Bantuan Jepun ini telah menyuntik dana sokongan bagi membantu kerajaan dalam memperkukuhkan ketahanan untuk tidak menerima bantuan dan pakej yang ketat oleh IMF.

Menerusi Diplomasi Ekonomi juga Tun Dr. Mahathir telah bertindak menutup CLOB yang berpusat di Singapura, uniknya, tindakan yang dilakukan tersebut tidak menimbulkan ketegangan yang jelas menjejaskan hubungan dua hala antara Kuala Lumpur dan Singapura. Menurut Salleh (2012) yang merupakan Pengurus Besar bagi Bursa Saham Kuala Lumpur sejak 1984 dan turut terlibat semasa krisis ekonomi 1997-98 melanda, secara jelas, tidak ada kesan yang lebih buruk pada negara yang di alami Malaysia selain daripada penarikan atau pengurangan kemudahan pinjaman yang diberikan kepada syarikat perniagaan, dan ini telah dilihat kesannya pada ketika berlakunya krisis kewangan 1997-98 (Salleh, 2012). Ketika wujudnya CLOB, banyak saham yang diniagakan di bursa saham Malaysia diurusniagakan secara "jualan singkat" (Short selling), iaitu pelabur asing dapat menjual saham yang mereka tidak miliki dan membeli semula apabila harga saham tersebut jatuh. Ini digambarkan oleh Salleh (2012) sebagai gejala "keuntungan atas angin". Apabila berlakunya krisis ekonomi 1997-98, barulah kerajaan Malaysia menyedari keadaan yang berlaku akibat CLOB, dan bertidak tegas menutup urus niaga CLOB yang berpusat di Singapura, namun, implikasi dari penutupan CLOB menjadi punca kepada pasaran saham di Malaysia merosot kedudukannya di kalangan pasaran ASEAN, bursa saham di Malaysia sudah tidak lagi menjadi bursa saham nombor satu di rantau ASEAN (Salleh, 2012). Menurut Prema-chandra (2010), tekanan ke atas ringgit Malaysia sejak Julai 1997 hingga 7 Januari 1998 sehingga menyusutkan mata wang Malaysia ke paras 50 peratus lebih rendah berbanding dollar Amerika Syarikat. Pada penghujung 1997, nilai saham komposit di BSKL juga telah menurun sebanyak 50 peratus dan menyebabkan pasaran saham Malaysia kehilangan AS\$225 bilion, sedangkan Malaysia pada tahun 1990 hingga 1995, direkodkan memperoleh US $\$ 26.7$ bilion pelaburan langsung asing (FDI) iaitu merangkumi 31.3 peratus dari keseluruhan jumlah FDI yang mengalir ke kalangan negara ASEAN (Dhillon, 2009).

Pada ketika sebelum berlakunya krisis ekonomi 1997-98, pasaran saham Malaysia terdedah dengan risiko kebocoran maklumat syarikat akibat daripada kewujudan CLOB di Singapura. Ramai pelabur asing menggunakan bank-bank di Singapura yang beroperasi di Malaysia untuk menyimpan rekod urus niaga saham syarikat Malaysia menerusi kegiatan CLOB. Pelabur asing dikesan lebih gemar menggunakan Singapura sebagai hub bagi membeli saham syarikat Malaysia berbanding berdagang secara langsung dengan bursa saham Malaysia. Menyedari gugatan dan masalah yang bakal berlaku pada Malaysia dari segi ekonomi, Salleh Majid sendiri telah mencadangkan kepada pihak kerajaan supaya mengambil langkah untuk menutup CLOB, tetapi tiada tindakan dilakukan sebelum berlakunya krisis ekonomi 1997-98 itu. Sebagai langkah memperkukuhkan peranan dan perkembangan pasaran saham Malaysia, menerusi aplikasi Diplomasi Ekonomi sebagai teras tindakan, pihak bursa Malaysia bertindak mempromosikannya di luar negara terutama di pusat-pusat kewangan utama seperti di New York, Boston, London, Zurich, Chicago dan Tokyo. Promosi yang digerakkan oleh Salleh Majid disesuaikan dengan lawatan Perdana Menteri ketika itu iaitu Tun Dr. Mahathir atau Timbalan Perdana Menteri pada ketika melawat ke luar negara. Dalam proses promosi menerusi aplikasi Diplomasi Ekonomi ditambah nilai Mahathiriskonomism, pelaksanaan yang dijalankan Malaysia memberikan kesan positif, dan ini dinyatakan Salleh (2012) mengenai kewibawaan Tun Dr. Mahathir dalam menjawab persoalan yang dibangkitkan para pelabur asing serta Tun Dr. Mahathir mampu memuaskan hati semua pihak dan beliau betul-betul faham mengenai apa yang diperkatakan. Kemampuan Tun Dr. Mahathir dalam memahami dan bertindak serta berkeupayaan bagi memperkukuhkan usaha menangani krisis ekonomi jelas diperlihatkan menerusi kenyataan Salleh (2012) yang memaparkan 
peranan dan keupayaan luar biasa Tun Dr. Mahathir dalam berhadapan masyarakat pemodal dan awam yang jelas memahami mengenai krisis ekonomi yang melanda dan mampu memberikan impak dalam meningkatkan keyakinan kepada kedudukan ekonomi Malaysia.

"Satu perkara yang saya perhatikan ialah ketika Perdana Menteri, Tun Dr. Mahathir menjawab soalan. Beliau begitu bersahaja walaupun untuk soalan-soalan yang susah. Selalunya mereka yang mendengar ceramah Dr. Mahathir ialah pengerusi-pengerusi bank pelaburan dan syarikat dana terbesar seperti Merill Lynch, Morgan Stanley dan lain-lain. Biasanya jawapan Dr. Mahathir memuaskan hati semua pihak dan beliau betul-betul faham mengenai apa yang diperkatakannya. Aura Dr. Mahathir berterusan. Saya pernah hadir pada satu majlis di Jeddah di mana beliau memberi ucapan selepas bersara. Sesi soal jawab begitu panjang kerana terlalu ramai yang bertanya dan beliau menjawabnya dengan baik... melalui ceramah di luar negara, dapatlah kita memperkenalkan bursa saham kepada lebih ramai pelabur asing sehinggakan pada 1994, Bank Negara terpaksa mengehadkan kemasukan wang ke dalam negara kerana terlampau banyak... kita juga pernah mencatat jumlah dagangan tertinggi dalam sejarah iaitu 2 bilion unit dalam tahun itu, suatu angka melebihi jumlah dagangan di Bursa Saham New York pada masa itu." (Salleh, 2012)

Dalam tindakan menangani krisis ekonomi 1997/98, pendekatan digunakan adalah bersifat Mahathirism, iaitu pendekatan berasaskan gaya kepimpinan dan pemikiran Dr. Mahathir yang tersendiri dan bebas dari pengaruh asing. IMF juga mengiktiraf kejayaan Malaysia dalam menyelesaikan krisis ekonomi 1997/98, di mana IMF dengan jelas semasa Kumpulan Lapan (G-8) tahunan di Evian, Perancis pada 2 Jun 2003 telah dinyatakan sendiri oleh Pengerusi IMF, Horst Kohler iaitu:-

\footnotetext{
"Malaysia has recapitalized its banks, its system is more transparent and the country has been able to deal with the non-performing loans" additionally, "Generally, Malaysia has improved the business climate" (Kaur, 2003).
}

Bahkan mantan ketua IMF, Michael Camdessus, di Paris seminggu sebelumnya mengatakan "They are (Malaysia) within the rules of the IMF which has no objection" (New Straits Times, 2003). Pendekatan Mahathiriskonomism adalah satu pendekatan yang berjaya, ini kerana beberapa tahun selepas krisis ekonomi melanda negara, Malaysia telah pulih dan memperbaiki iklim ekonomi ke arah pertumbuhan. Pada bulan Jun 2003, Bank Negara Malaysia mengumumkan bahawa pertumbuhan KDNK adalah 4\%, menunjukkan bahawa ekonomi Malaysia bertambah baik. Ini juga menyokong pernyataan yang diumumkan oleh Menteri Perdagangan Antarabangsa dan Industri, Dato Seri Rafidah Aziz, bahawa sehingga April 2003 Malaysia telah mencatatkan lebihan dalam perdagangan antarabangsa bernilai RM5.77 bilion (US \$ 1.52 bilion). Ia memperjelaskan bahawa tanpa bantuan IMF, yang diketahui menghalang kebebasan kewangan negara-negara penerima pinjaman, Malaysia mencapai kejayaan dengan pelbagai inisiatif pemulihan termasuk aplikasi Diplomasi Ekonomi yang diamalkan dalam pendekatan Mahathiriskonomism.

\section{Kesimpulan}

Schuman (2009) menegaskan bahawa pendekatan Dr. Mahathir banyak dipengaruhi oleh pendekatan dan pengamalan pembangunan yang diamalkan oleh Jepun dan Korea Selatan. Menerusi pendekatan yang dikenali sebagai 'model asia' yang dipelopori Jepun telah juga diadaptasi oleh Dr. Mahathir dalam konteks Malaysia bagi memberikan satu model yang menggambarkan hubungan kesaling bergantungan antara kerajaan dan perniagaan dalam sistem ekonomi negara dengan istilah "Malaysia Inc" atau "Pensyarikatan Malaysia". Pendekatan yang dilaksanakan Malaysia pada pentadbiran Dr. Mahathir secara jelas adalah berkaitan rapat dengan personaliti Dr. Mahathir sendiri (Schuman, 2009). Secara kesimpulannya, model pembangunan Malaysia adalah berasaskan kepada kekuatan Dr. Mahathir dalam memberikan inspirasi dan hala tuju hingga membolehkan beberapa model dan dasar pembangunan Malaysia diperkenalkan pada era pentadbiran beliau. Schuman (2009) menyifatkan Dr. Mahathir dalam penulisan beliau sebagai 'leaders of Miracle' (pemimpin ajaib) dan menyatakan Dr. Mahathir bukan sahaja seorang nasionalis tetapi juga merupakan aktivis Melayu. Peranan Tun Dr. Mahathir secara langsung diperjelaskan oleh Mahani (2002) bahawa Tun Dr. Mahathir sendiri 
mempunyai keupayaan tersendiri dalam proses penyelesaian masalah dan mampu mengemukakan strategi yang membantu mengatasi masalah dengan pemahaman terhadap sesuatu perkara yang sukar.

PM Mahathir has the ability to approach a problem from a sound appreciation of technical details, and then develop a strategy from that foundation. (Mahani; 2002: 254)

Hujahan Schuman (2009) itu memperjelaskan bahawa Dr. Mahathir ini seorang yang berprinsip yang kuat berpegang dengan usaha kuat bagi membawa Malaysia berubah kepada sebuah negara berdaya saing yang maju. Dr. Mahathir berjaya membawa Malaysia sebagai sebuah negara Islam di dunia yang berbeza dengan lain-lain negara Islam di mana Malaysia sebagai sebuah negara yang didominasi secara majoritinya oleh umat Islam tetapi memiliki keupayaan ekonomi yang mapan serta mampu mendepani kemajuan dan diiktiraf peringkat antarabangsa (Schuman, 2009). Menurut Dhillon (2009), kejayaan Malaysia yang diistilahkan sebagai 'Malaysian miracle' dicapai menerusi 'formula Mahathir' yang dilaksanakan menerusi pelbagai dimensi usaha termasuklah dalam aspek memodenkan negara, pengindustrian, keterbukaan atau liberalisasi serta penswastaan dalam aspek pembangunan dan pertumbuhan ekonomi negara.

\section{Rujukan}

Anthony, D. S. (1996). The resurgence of nationalism? Myth and memory in the renewal of nations. British Journal of sociology, 47, 593.

Anthony, D. S. (1972). Theories of nationalism, Harper and Row, New York.

Anthony, D. S. (1995). Nation and nationalism in a global era, Polity Press, Cambridge.

Aaron, N., (2000). The Causes of the 1997-98 Asian Economic Crisis: A review of the academic literature and Comparison between Indonesia and South Korea. Department of Management Birkbeck, University of London.

Ahmad Atory Hussain. (2000). Analisis dasar awam: peranan kerajaan mengatasi masalah ekonomi dalam sistem pasaran bebas. Utusan Publications \& Distributors Sdn Bhd, Kuala Lumpur.

Arturo, B., Yrjo, K., \& Vicente, P. (2004). Corporate Financial Policies and Performance Around Currency Crises. Journal of Business, 77(4), 749-795.

Athukorala, P. (2008). The Malaysian capital controls: a success story?, Asian Economic Papers, The Earth Institute at Columbia University and The Massachussetts Institute of Technology.

Benedict, A. (1991). Imagined communities: Reflection on the origin and spread of nationalism, $2^{\text {nd }}$ Ed, Verso, London.

Chamhuri Siwar. (2007). Pengalaman Krisis Ekonomi di Negara-Negara Asia Timur, di dalam Nor Aini Haji Idris, Kegawatan Ekonomi Impak Terhadap Golongan Berpendapatan Rendah. Kuala Lumpur: Dewan Bahasa dan Pustaka.

Che Wan Badrul Alias. (27 Disember 2011). Cara Malaysia tangani krisis 1997 diiktiraf, Berita Harian, 27 Disember 2011.

Chris, B. (1992). International relations theory: New normative approaches, Harvester Wheatsheaf, London.

Dhillon, K. S. (2009). Malaysian Foreign Policy in The Mahathir Era 1981-2003. Singapore: NUS Press.

Donald, M. S. (1998). National Security: Defence policy in a changed international order. St Martin's Press: New York.

Edward, N. M. (1995)., Economic Determinants of Democracy. American Sociological Review, 60(6), 966-982.

Francis, F. (1992). The end of history and the last man. Hamish Hamilton, London.

Hanke, S. (2003). Suharto, Too, Was a Victim of Regime Change. The Australian (newspaper), 29 April, 2003.

Hans, M. (1948). Politics Among Nations, The Struggles For Power And Peace. New York: Alfred Knopf.

Harold, D. L. (1986). Politik, Siapa Mendapat Apa, Bila, Bagaimana. (Terj). Kuala Lumpur : Dewan Bahasa dan Pustaka. 
Harris, S. (2000). Asian Multilateralism Institutions and Their Response to The Asian Economic Crisis: The Regional and Global Implications'. Pacific Review, 13,421-451.

Ishak Yussof, Mohd Shukri Hajinoor dan Zulkifly Osman. (2009). Globalisation and Malaysia's economy di dalam Ishak Yussof, Malaysia's economy: past, present \& future, Malaysian Strategic Research Centre, Kuala Lumpur.

James, M. (1982). The Community of States. London: George Allen \& Unwin.

Jim, G. (2001). Economic Crisis in Asia: The Case of Thailand. Economic Geography, 77(2), 122147.

Joseph, S. N. (2000). Understanding International Conflicts, An Introduction to Theory and History. New York : Longman.

Jurg, M. G. (1994). World views and theories of international relations, Macmillan, London.

Karen, M. (1979). Essentials Of International Relations. New York: W.W. Norton \& Company.

Kaur, H. (2003). IMF Praises Malaysia's Financial Management', New Straits Times, 3 Jun 2003.

Keating, P. (2000), Engagement: Astralia Faces The Asia-Pacific. Sydney: Macmillan.

Kenneth, W. (1979). Theory of International Politics. Massachusetts:Adison-Wesley.

K. J. Holsti (1991). Power, Capability And Influence In International Politics. Dalam Charles W. Kegley, Jr \& Eugenc R. Wittkof (Edt) The Global Agenda: Issue And Perspectives. London: McGraw Hill Inc.

K. Ramanathan (2000). Konsep Asas Politik. Pulau Pinang: Alms Digital Enterprise.

Khoo, B. T. (1995). Paradoxes of Mahathirism: an intellectual biography of Mahathir Mohamad. Oxforf University Press: Singapore.

Lyons, G. (2014). The consolations of economics: Good news in the wake of the financial crisis. London: Faber \& Faber.

Mahani Zainal Abidin (1999). Malaysia's Economy: Crisis and Recovery in The Financial Crisis on Malaysia: The Economic and Political Consequences, Institute of Southeast Asian Studies, 6, October 1999.

Mahathir. (1994). The Awakening. Uni-Strength Sdn. Bhd: Labuan.

Mahathir Mohamad (2003). Ucapan Dasar Presiden di Persidangan Agung UMNO ke 54: Mengenali Ancaman Terhadap Bangsa, Agama dan Negara. Berita Harian, 20 Jun 2003.

Mahathir Mohamad (1999). Case Study For A Country Under Economic Stress', Mainichi, Tokyo, August 2 $2^{\text {nd }}, 1999$.

Mahathir Mohamad. (9 Februari 1998). Ucapan di The Official Dinner In Honour Of His Excellency Rafic Hariri Prime Minister Of The Republic of Lebanon, di Seri Perdana, Kuala Lumpur dalam Collection of Mahathir's Speeches 1998. Jabatan Penerangan Malaysia, Kementerian Penerangan Malaysia, 6-14.

Mahathir Mohamad. (29 Januari 1999). Ucapan di The World Economic Forum Working Lunch, di Davos, Switzerland dalam Collection of Mahathir's Speeches 1999. Jabatan Penerangan Malaysia, Kementerian Penerangan Malaysia, 9.

Mahathir Mohamad. (28 November 1997). Ucapan di The Business Leaders Dialogue, di Tokyo, Jepun dalam Collection of Mahathir's Speeches 1997. Jabatan Penerangan Malaysia, Kementerian Penerangan Malaysia, 463-480.

Mahathir Mohamad (1 September 1998). The Panel Discussion With Prime Minister, di Radio Televisyen Malaysia (RTM), Angkaspuri, Kuala Lumpur dalam Collection of Mahathir's Speeches 1998. Jabatan Penerangan Malaysia, Kementerian Penerangan Malaysia, 185-224.

Mahathir Mohamad (2 September 1998). Ucapan di The 12th Conference of The Heads of State or Heads of Government of The Non-Aligned Countries, Durban, South Africa dalam Collection of Mahathir's Speeches 1998. Jabatan Penerangan Malaysia, Kementerian Penerangan Malaysia, 225-243.

Mahathir Mohamad (2003). Ucapan Dasar Presiden di Persidangan Agung UMNO ke 54: 'Mengenali Ancaman Terhadap Bangsa, Agama dan Negara'. Berita Harian, 20 Jun 2003.

Mahathir Mohamad (1999). Case Study For A Country Under Economic Stress. Mainichi, Tokyo, August 2 $2^{\text {nd }}, 1999$.

Md.Shukri Shuib (2007). Mahathiriskonomisme Mengekang Ancaman Kedaulatan Negara, Dewan Ekonomi, 49-51. 
Md.Shukri Shuib. (2007). Mahathiriskonomism: Sorotan Krisis Ekonomi 1997/98. Kertas kerja dalam Seminar Internasional Memperkuat Landasan Hubungan Indonesia-Malaysia. Universitas Padjadjaran, Bandung, Indonesia, 15-16 Disember.

Md.Shukri Shuib, Mohamad Faisol Keling dan Mohd Na'eim Ajis. (2008). The Concept of Mahathiriskonomism: A Significant Model for Economic Turnmoil. Kertas kerja dalam Seminar International Conference on International Studies (ICIS) 2008. Institute Diplomacy and Foreign Relations (IDFR), Kuala Lumpur, 4-6 Disember.

Md. Shukri Shuib. (2008). Krisis ekonomi global bukan sebab kerajaan tak pandai urus ekonomi. Berita Harian. 11 Disember: 24.

Md. Shukri Shuib (2007). Kejayaan Tadbir Urus Ekonomi Malaysia: Model Inovasi Bertaraf Dunia. Dewan Ekonomi. July

Md. Shukri Shuib (2007). Sepuluh Tahun Kejayaan Pasca Kegawatan 1997. Dewan Ekonomi. Julai.

Md.Shukri Shuib (2007). 'Mahathiriskonomisme': mengekang ancaman kedaulatan negara melalui ekonomi. Dewan Ekonomi. Ogos

Mohammed Ayoob. (1995). Security in the Third World: the worm about to turn?, International Affairs, 60, 1.

Mohamad Faisol Keling et.al. (2006). Konsep asas hubungan antarabangsa dan pengajian strategi. Universiti Utara Malaysia: Sintok.

Mohd Yusof, A. (1990). Continuity and change in Malaysia's foreign policy, 1981-1986. Phd Thesis. Tufts University: UMI.

Muhammad Azli Shukri (2007). Apakah Yang Sebenarnya Berlaku Pada Julai 1997. Dewan Ekonomi. Julai

Manuel, D. (1998). The Political and Social Implications of the Asian Crisis. Philippine Journal of Third World Studies, 13(4).

Mohd Hizam Hanafiah \& Zafir Mohd Makhbul (2008). Kesan Kegawatan Ekonomi ke atas Perniagaan Kecil: Penemuan dalam Perniagaan Francais. Jurnal Ekonomi Malaysia, 42, 45-63.

Nor Aini Haji Idris, 2007. Kemiskinan dan Krisis Ekonomi: Analisis Terhadap Tindakan Pelan Pemulihan Ekonomi Negara (PPEN), di dalam Nor Aini Haji Idris, Kegawatan Ekonomi Impak Terhadap Golongan Berpendapatan Rendah. Kuala Lumpur: Dewan Bahasa dan Pustaka.

Nor Mohamed Yakcop (2009). Rahsia di sebalik krisis ekonomi, Berita Harian, 14 Mac 2009.

Rais Yatim. (2011). 1Malaysia Cabinet: Reflecting on cabinet governing. Mashi Publication Sdn. Bhd: Selangor.

Saadiah Mohamad. (2009). Malaysia's experience in monetary and exchange rate policy di dalam Ishak Yussof, Malaysia's economy: past, present \& future, Malaysian Strategic Research Centre, Kuala Lumpur.

Sachs, J. \& Radelet, S. (1998). The Onset of the East Asian Financial Crisis. NBER Working Paper No. 6680, Ogos 1998.

Sulaiman, M. (2013). Good human capital leads to top economy. New Straits Times, 25 Julai 2013.

Stiglitz, E. J. (2002), 'Globalization and its Discontents', Victoria, Australia: Penguin Books.

Surtahman Kastin Hasan dan Ishak Yussof. 2009. Bab 1 Economic development in Malaysia since independent di dalam Ishak Yussof, Malaysia's economy: past, present \& future, Malaysian Strategic Research Centre, Kuala Lumpur.

Schuman, M. (2009). The miracle: the epic story of Asia's quest for wealth. New York: Harper Business.

Scot Burchill et.al (2001). Theories Of International Relations. New York: Palgrave. hlm 70. lihat juga Martin Griffiths dan Terry Ocallaghan (2002). International Relations, The Key Concepts. London: Routledge.

Sivamurugan Pandian. (2005). Legasi Mahathir. Utusan Publication \& Distributors Sdn Bhd: Kuala Lumpur.

Sulaiman Mahbob. (2013). Good human capital leads to top economy. New Straits Times, 25 Julai 2013.

Timothy Lane et al. (1999). IMF- Supported programs in Indonesia, Korea and Thailand: A preliminary assessment. IMF: Washington.

Wong Sulong. (2011). Notes to the Prime Minister: The Untold Story of How Malaysia Beat the Currency Speculators. MPH Publishing: Kuala Lumpur. 
Malaysian Journal of Social Sciences and Humanities (MJSSH), Volume 5, Issue 12, (page 392 - 404), 2020 DOI: https://doi.org/10.47405/mjssh.v5i12.622

Zakaria Haji Ahmad \& Baladas Ghoshal. (1999). The political future of ASEAN after the Asian crisis. International Affairs, 75(4), 759-778.

Zaherawati Zakaria, Zaliha Hj. Hussin, Nazni Noordin \& Mohd Zoolhilmie Mohamed Sawal (2010). Voice of Academia, 5(1), 79-96. 